University of Nebraska - Lincoln

DigitalCommons@University of Nebraska - Lincoln

Roman L. Hruska U.S. Meat Animal Research

U.S. Department of Agriculture: Agricultural Center

Research Service, Lincoln, Nebraska

2005

\title{
Post-Harvest Interventions to Reduce/Eliminate Pathogens in Beef
}

M. Koohmaraie

USDA-ARS, koohmaraie@email.marc.usda.gov

T. M. Arthur

USDA-ARS, terrance.arthur@ars.usda.gov

J. M. Bosilevac

USDA-ARS, mick.bosilevac@ars.usda.gov

M. Guerini

USDA-ARS

S. D. Shackelford

USDA-ARS

See next page for additional authors

Follow this and additional works at: https://digitalcommons.unl.edu/hruskareports

Koohmaraie, M.; Arthur, T. M.; Bosilevac, J. M.; Guerini, M.; Shackelford, S. D.; and Wheeler, T. L., "PostHarvest Interventions to Reduce/Eliminate Pathogens in Beef" (2005). Roman L. Hruska U.S. Meat Animal Research Center. 243.

https://digitalcommons.unl.edu/hruskareports/243

This Article is brought to you for free and open access by the U.S. Department of Agriculture: Agricultural Research Service, Lincoln, Nebraska at DigitalCommons@University of Nebraska - Lincoln. It has been accepted for inclusion in Roman L. Hruska U.S. Meat Animal Research Center by an authorized administrator of DigitalCommons@University of Nebraska - Lincoln. 


\section{Authors}

M. Koohmaraie, T. M. Arthur, J. M. Bosilevac, M. Guerini, S. D. Shackelford, and T. L. Wheeler 


\title{
Post-harvest interventions to reduce/eliminate pathogens in beef
}

\author{
M. Koohmaraie *, T.M. Arthur, J.M. Bosilevac, M. Guerini, S.D. Shackelford, T.L. Wheeler \\ Roman L. Hruska US Meat Animal Research Center, ARS, USDA, Clay Center, P.O. Box 166, Spur 18-D, NE 68933-0166, USA
}

\begin{abstract}
In 1999 the foodborne pathogens Salmonella, Listeria, Campylobacter, and Escherichia coli (both O157 and non-O157) were estimated to cause more than 6 million illnesses and approximately 9000 deaths each year. However, the most recent Centers for Disease Control and Prevention report on the sources and incidence of foodborne disease, released in 2004, has shown a dramatic decrease in E. coli $\mathrm{O} 157: \mathrm{H} 7$ infections. Since raw beef products are the most frequently foodborne sources of these pathogens, the results of this report demonstrate that the microbiological quality of raw beef has improved greatly. During the intervening years, post-harvest interventions have continually improved, with new attention to hide decontamination and innovative treatments of carcasses. In addition, a system to hold and test beef trim or ground beef for E. coli O157:H7 before its release into commerce has provided an even greater level of safety. In this paper, we review the latest information on the prevalence of E. coli O157:H7 and other pathogens on beef, the evidence identifying the hide as the primary source of pathogens on beef carcasses, the efficacy of various hide and carcass interventions, and other developments that have led or have the potential to lead to even greater improvements in the microbial quality of beef.
\end{abstract}

Published by Elsevier Ltd.

Keywords: Escherichia coli O157:H7; Non-O157 Shiga toxin-producing E. coli; Salmonella; Interventions; Test-and-hold; Pre-harvest versus postharvest interventions

\section{Contents}

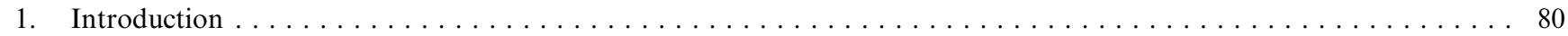

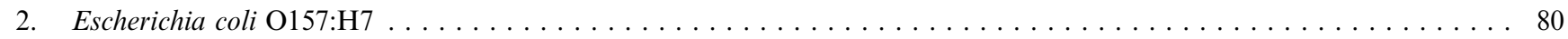

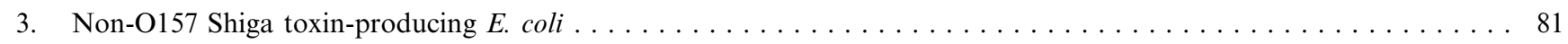

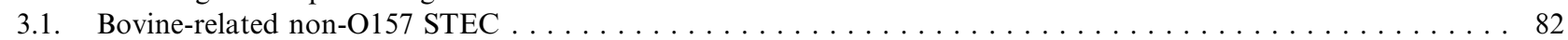

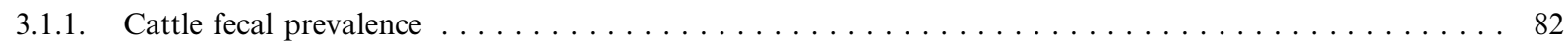

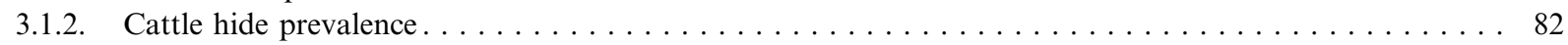

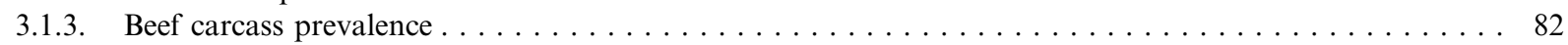

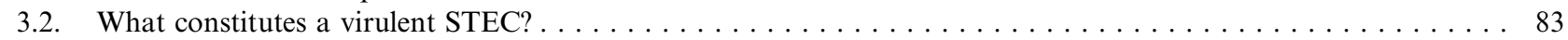

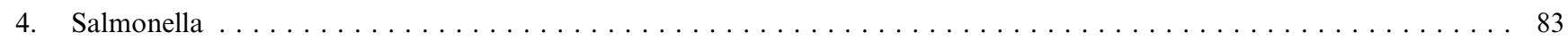

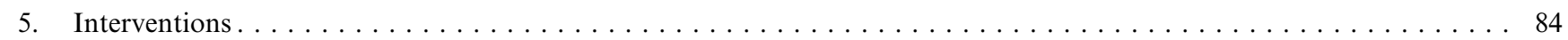

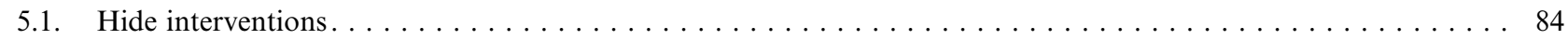

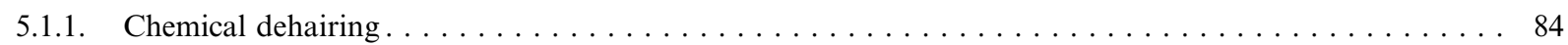

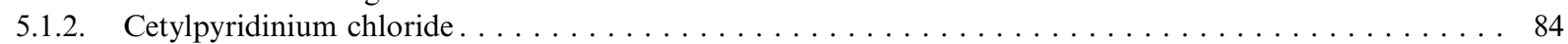

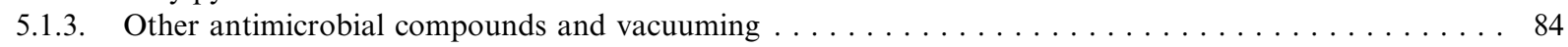

\footnotetext{
${ }^{*}$ Corresponding author. Tel.: +1 402762 4221; fax: +1 4027624149 .

E-mail address: koohmaraie@email.marc.usda.gov (M. Koohmaraie).
} 


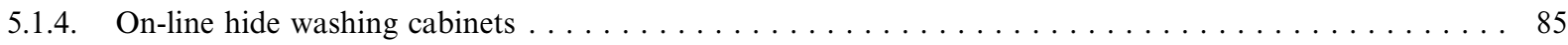

5.1.5. Ozonated and electrolyzed oxidizing $($ EO) waters $\ldots \ldots \ldots \ldots \ldots \ldots$

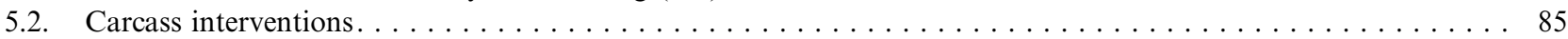

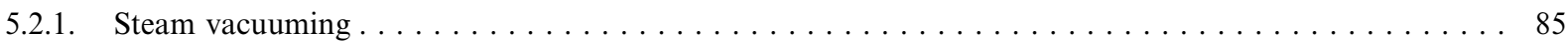

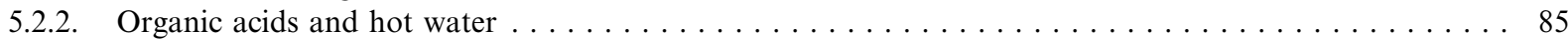

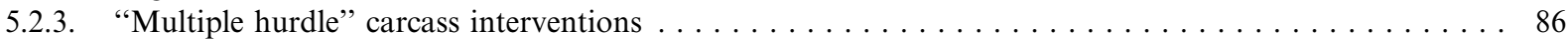

5.2.4. Low-dose, low-penetrating radiation (electron beam) $\ldots \ldots \ldots \ldots \ldots$

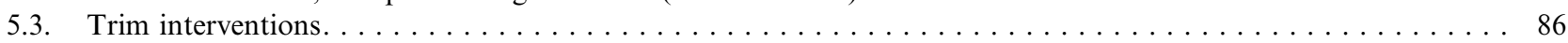

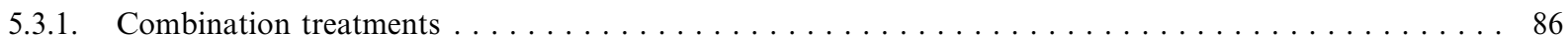

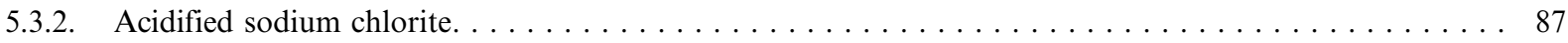

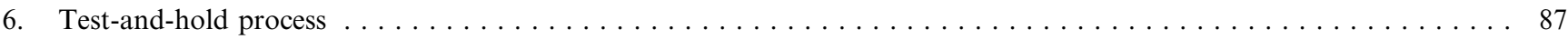

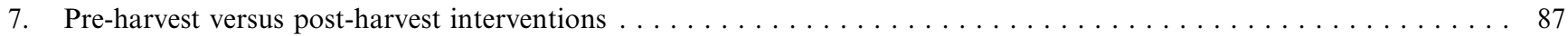

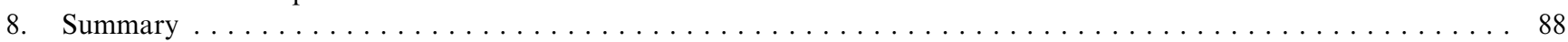

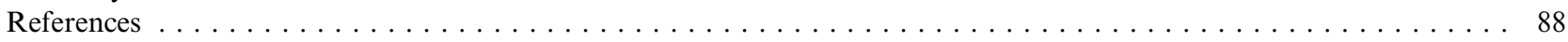

\section{Introduction}

Foodborne pathogens have been estimated to cause $>6$ million illnesses and approximately 9000 deaths each year (Mead et al., 1999). Bacterial pathogens contribute to $\sim 60 \%$ of the foodborne illnesses that lead to hospitalization and account for nearly two-thirds of the estimated number of foodborne pathogen-related deaths. Mead et al. (1999) estimated that Salmonella spp. caused $\sim 26 \%$ and $>30 \%$, Listeria spp. accounted for $\sim 4 \%$ and $\sim 28 \%$, Campylobacter spp. caused $\sim 17 \%$ and $>5 \%$, and Escherichia coli, both $\mathrm{O} 157$ and non-O157, accounted for $\sim 5 \%$ and $>4 \%$ of foodborne illness-related hospitalizations and foodborne pathogen-related deaths, respectively.

Listeria is more often associated with ready-to-eat products and Campylobacter is more often associated with poultry and produce, while Salmonella can be found in all varieties of food products. E. coli O157:H7 and non-O157 STEC are most frequently associated with raw beef products and, thus, will be the focus of this review. The best way to control and eliminate pathogens is to understand their sources and prevalence in the environment. Through the efforts of the beef processing industry and many groups of researchers, the microbiological quality of raw beef has greatly improved. Post-harvest interventions have been continually improved, with new attention to hide decontamination and innovative treatments of carcasses. In addition, a system to hold and test trim or ground beef for $E$. coli O157:H7 before release into commerce has provided an even greater level of safety. The most recent Centers for Disease Control and Prevention (CDC) report on the sources and incidence of foodborne disease has shown a dramatic decrease in $E$. coli O157:H7 infections (CDC, 2004). In this paper, we will review the latest information, primarily from our laboratory, on prevalence of pathogens on beef, the evidence identifying the hide as the primary source of pathogens on beef carcasses, the efficacy of various hide and carcass interventions, and other developments that have led or will lead to even greater improvements in the microbiological quality of beef.

\section{Escherichia coli 0157:H7}

Of the three pathogens discussed herein ( $E$. coli O157:H7, non-O157 STEC, and Salmonella spp.), the most significant is enterohemorrhagic $E$. coli $\mathrm{O} 157: \mathrm{H} 7$. The reason for the focus on E. coli O157:H7 is the designation of $E$. coli $\mathrm{O} 157: \mathrm{H} 7$ as an adulterant in ground beef and the consequences of such a policy for the beef processing industry. This bacterium is capable of producing large quantities of toxins (Shiga toxins) that cause severe damage to the intestinal lining. In the early 1980s, E. coli O157:H7 gained recognition as the causative agent for an outbreak of severe bloody diarrhea traced to consumption of improperly prepared hamburgers (Johnson, Lior, \& Bezanson, 1983; Riley et al., 1983). It is now established that $E$. coli O157:H7 can be found in animals and associated with contaminated meat (Chapman et al., 1993; Hancock, Besser, Lejeune, Davis, \& Rice, 2001). E. coli serotype O157:H7 and its significance to public health and commerce are well documented.

A study of the prevalence of $E$. coli $\mathrm{O} 157: \mathrm{H} 7$ in feces, hides and carcasses of beef cattle at processing plants in the late summer months (July and August, 1999) found that $28 \%$ of feces and $11 \%$ of hides tested positive for the presence of this pathogen (Elder et al., 2000). This report also found that $\sim 45 \%$ of pre-evisceration carcasses were positive for $\mathrm{O} 157: \mathrm{H} 7$, but as the processing continued and antimicrobial interventions were applied, the number of positive samples declined to $\sim 20 \%$ (post-evisceration) and was $2 \%$ post-intervention. This report 
showed that the prevalence of E. coli $\mathrm{O} 157: \mathrm{H} 7$ on carcasses was higher than previously thought (USDA, FSIS, 1994).

To advance the priority of upgrading food safety in beef products, new research tools were needed to help investigators isolate, identify, and track the source of bacterial contamination. Hides were suggested to be a source of carcass contamination (Bell et al., 1997). To trace the origin of carcass contamination, a genotyping approach (pulsed-field gel electrophoresis, PFGE) was used to determine whether isolates found on carcasses came from the same animal or from outside sources (for example, cutting tools, assembly line, other animals, etc.). Barkocy-Gallagher et al. (2001) used PFGE to demonstrate that $>66 \%$ of $E$. coli $\mathrm{O} 157: \mathrm{H} 7$ identified on a carcass were traceable to the same animal earlier in the process.

The Barkocy-Gallagher et al. (2001) and the Elder et al. (2000) studies suggested that hides were the source of E. coli $\mathrm{O} 157: \mathrm{H} 7$ on carcasses. However, hide prevalence data did not support this notion. Therefore, we hypothesized that the methodology applied in that study had underestimated the prevalence of E. coli $\mathrm{O} 157: \mathrm{H} 7$ on hides and we pursued the development of an improved method for detection and isolation of foodborne bacteria. The resulting "MRU Method" (Barkocy-Gallagher et al., 2002) uses selective temperature incubation in non-selective media as a primary enrichment. Bacterial recovery and enumeration are accomplished by using immunomagnetic separation then plating on selective media. In addition to improving assay sensitivity, this enrichment provides a system whereby multiple pathogens (E. coli O157:H7, non-O157 STEC, and Salmonella) can be isolated concurrently, as opposed to the independent recovery methods traditionally employed.

Using the MRU methodology, researchers surveyed beef processing plants during four different seasons from spring of 2001 through winter of 2002 (Barkocy-Gallagher et al., 2003). The prevalence of E. coli O157:H7 in fecal samples was highest in the summer and lowest in the winter. The incidence of these bacteria on hides was highest in spring and summer (74\%), slightly lower in fall, and much lower in winter $(29.4 \%$; BarkocyGallagher et al., 2003). Prevalence of E. coli O157:H7 on pre-evisceration carcasses was highest in spring and summer $(\sim 39 \%)$ and lowest in winter $(\sim 1 \%)$. Of the 1,232 post-intervention carcasses sampled during the four seasons, only $15(1.2 \%)$ tested positive for the presence of E. coli O157:H7 (Barkocy-Gallagher et al., 2003). These data supported a general conclusion that low numbers of $E$. coli $\mathrm{O} 157: \mathrm{H} 7$ could be introduced into beef products at fed-cattle slaughter plants.

These studies (Barkocy-Gallagher et al., 2003; Bell et al., 1997) and others (Rivera-Betancourt et al., 2004; Small et al., 2002) provided convincing evidence that hides were the source of carcass contamination. How- ever, the definitive evidence incriminating hides as the primary source of carcass contamination came from the results of chemical dehairing experiments. Nou et al. (2003) showed that E. coli O157:H7-positive carcasses were reduced from $50 \%$ to $1 \%$ by chemical dehairing. Knowing the source and level of contamination is critical for developing improved processing and intervention strategies.

In order to identify critical control points during the harvesting process, Arthur et al. (2004) developed a five-point sampling protocol that allows processors to evaluate the efficacy of their on-line antimicrobial interventions. Using this sampling protocol, Arthur et al. (2004) demonstrated a correlation between the prevalence of indicator organisms (aerobic bacteria [APC] and Enterobacteriaceae [EBC]) and E. coli O157:H7. Notably, samples containing higher levels of APC and EBC were more likely to contain detectable levels of E. coli $\mathrm{O} 157: \mathrm{H} 7$. This sampling protocol is non-invasive and can be performed with high efficiency and accuracy on a production line. It also provides a comprehensive appraisal of plant microbial hygiene at multiple points throughout the harvesting process. Integration of this sampling protocol into the standard operating procedures of beef processing plants has occurred.

\section{Non-O157 Shiga toxin-producing $E$. coli}

The Shiga toxin-producing E. coli (STEC) strain most frequently associated with clinical disease in the United States is serotype O157:H7 (Mead et al., 1999; Nataro \& Kaper, 1998). However, other STEC can cause the same types of disease as serotype O157:H7. It has been estimated that E. coli $\mathrm{O} 157: \mathrm{H} 7$ causes twothirds of the human EHEC infections in the United States, with the other one-third of cases attributed to the non-O157 STEC population (Mead et al., 1999). This estimation may be biased towards E. coli O157:H7 due to its relative ease of detection compared to that of non-O157 STEC strains. No universal IMS reagents or chromogenic media are available for detection and isolation of all STEC, as there are for E. coli O157:H7. STEC identification depends on either detection of the stx genes by PCR or hybridization, or detection of the Shiga toxin proteins by ELISA or cell cytotoxicity assay. These methods are not as sensitive, are more costly, and require more technical expertise than those for E. coli O157:H7.

As of $1999,50 \%$ of the clinical laboratories within the CDC's Active Surveillance Network (FoodNet) were screening all stool samples for O157, while only $3 \%$ reported having ever screened for Shiga toxins by immunoassay to detect non-O157 STEC (Griffin, Mead, Van Gilder, Hunte, \& Strockbine, 2001). Few studies have used unbiased methods to evaluate the relative 
frequencies at which $\mathrm{O} 157$ and non-O157 STEC cause human disease. One such survey sampled 335 diarrheal stools from patients in Nebraska and determined that 14 contained Shiga toxins. STEC isolates could only be cultured from 13 of these samples. Six samples were positive for E. coli $\mathrm{O} 157: \mathrm{H} 7$ and seven were positive for non-O157 STEC (serotypes included O26:H11,

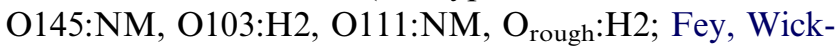
ert, Rupp, Safranek, \& Hinrichs, 2000). A similar study surveyed 270 stool specimens from patients in Virginia. Of the eleven STEC positive samples, six were confirmed as $E$. coli $\mathrm{O} 157: \mathrm{H} 7$ while five were proven to be nonO157 STEC (serotypes included O88, O103, O111, and $\mathrm{O}_{\text {rough }}$; Park, Gates, Vandel, \& Hixon, 1996). Infectious doses determined from various outbreaks also have shown similar results for O157 $(<50$ organisms) and non-O157 STEC (approximately 10 organisms for O111; Paton et al., 1996; Tilden et al., 1996). The E. coli O157 serogroup averages about 35 disease outbreaks per year in the United States, while non-O157 STEC have only been identified as the causative agent in three US outbreaks, none of which were directly linked to contaminated meat or other bovine-related sources (CDC, 2000; Feng, Weagant, \& Monday, 2001; McCarthy et al., 2001). Cattle are considered to be the primary reservoir for both $\mathrm{O} 157$ and non-O157 STEC (Bettelheim, 2000). Non-O157 STEC are the pathogens most likely to cause concern for the meat industry in the coming years.

\subsection{Bovine-related non-O157 STEC}

\subsubsection{Cattle fecal prevalence}

The prevalence of non-O157 STEC in the feces of beef cattle in the United States has scarcely been studied. Barkocy-Gallagher et al. (2003) found the non-O157 STEC prevalence in feces of fed beef cattle presented for slaughter ranged from $13.9 \%$ to $27.1 \%$ depending on the season of the year. Reported levels of nonO157 STEC in the feces of dairy cattle in the United States ranged from $5.8 \%$ to $19.0 \%$ (Cray, Thomas, Schneider, \& Moon, 1996; Wachsmuth et al., 1991; Wells et al., 1991). There have been several studies of fecal prevalence of non-O157 STEC in beef cattle from other countries. For example, 3.5\% of fecal samples from Canada's Prince Edward Island tested positive (Schurman, Hariharan, Heaney, \& Rahn, 2000) and even higher numbers were reported in France where two studies recovered non-O157 STEC from $7.9 \%$ and $34 \%$ of fecal samples (Pradel et al., 2000; Rogerie et al., 2001). PCR results reported by these groups indicated even higher levels of STEC were present, as stx genes were identified in $18 \%$ and $70 \%$ of the samples (Pradel et al., 2000; Rogerie et al., 2001). Shinagawa et al. (2000) reported levels of stx genes present in feces from healthy Japanese cattle ranged from $39.4 \%$ to
$78.9 \%$, depending on the age of the cattle, with calves 2 to $8 \mathrm{mo}$ of age having the highest prevalence. In a similar study, Kobayashi et al. (2001) used a nested PCR approach to detect stx genes in $100 \%$ of the cattle fecal samples tested. High levels of non-O157 STEC present in fecal samples of healthy cattle also were reported in Argentina (44\%; Parma et al., 2000) and Spain (35\%; Blanco et al., 1997).

\subsubsection{Cattle hide prevalence}

To the best of our knowledge, the only study that investigated the prevalence of non-O157 STEC on the hides of cattle was Barkocy-Gallagher et al. (2003). In that study, we observed seasonal variation in the prevalence of STEC on the hides of fed-beef cattle. Likewise we observed seasonal variation in the frequency of st $x$ positive samples. However, whereas STEC prevalence ranged from a low of $43 \%$ in the spring to a high of $78 \%$ in the fall, the frequency of stx-positive samples was lowest in the winter (88\%) and highest in the summer $(97 \%)$. That is, the rates of STEC isolation did not mirror the trend in the frequency of stx-positive samples. The authors hypothesized that the discrepancy may have been caused by the variation in background flora and its effects on the two methodologies. STEC strain isolation was performed using colony hybridization, which is impacted heavily by background flora, whereas the stx gene was detected by PCR, a method less affected by changes in background.

\subsubsection{Beef carcass prevalence}

We have shown that $53.9 \%$ of beef carcasses in large US processing plants were positive for at least one strain of non-O157 STEC prior to evisceration, but the prevalence was reduced to $8.3 \%$ of carcasses carrying STEC at post-processing by using various intervention strategies (steam vacuum, hot water, organic acids, and steam pasteurization; Arthur, Barkocy-Gallagher, Rivera-Betancourt, \& Koohmaraie, 2002). These samples were collected during the summer months, which have been associated with peak prevalence for bovine STEC carriage (Van Donkersgoed, Graham, \& Gannon, 1999). Similar data obtained by Barkocy-Gallagher et al. (2003) found $64.9 \%$ of pre-evisceration carcasses and $4 \%$ of post-intervention carcasses carried non-O157 STEC during the summer. Again, results obtained using PCR showed that many more carcasses, $98.7 \%$ of preevisceration and $10.6 \%$ of post-intervention, harbored the stx gene (Barkocy-Gallagher et al., 2003).

Two previous studies, one from France and the other from Hong Kong, reported lower post-processing nonO157 STEC prevalence (1.9\% and 1.7\%, respectively) on carcasses (Leung, Yam, Ng, \& Peiris, 2001; Rogerie et al., 2001). The differences in reported prevalence levels could come from a variety of factors, but are most likely due to dissimilar methodologies used for STEC isola- 
tion. Both studies reported higher levels of contamination when samples were surveyed by PCR, 10.7\% and $11.4 \%$ for France and Hong Kong, respectively (Leung et al., 2001; Rogerie et al., 2001), indicating a prevalence level similar to what has been described in the United States.

Prevalence data for carcasses following antimicrobial interventions indicate whether the target organism was still present at the time of sampling, but do not indicate the pathogen levels on those carcasses. Barkocy-Gallagher et al. (2003) used a most probable number technique to enumerate the STEC population on carcasses following the application of antimicrobial interventions. Of 199 carcasses that were PCR-positive for the stx gene, 191 carried st $x$-containing cells at a density of $<3.0$ cells per $100 \mathrm{~cm}^{2}$. The density of $s t x$-carrying cells on the other eight carcasses ranged from 3.0 to 38.2 cells per $100 \mathrm{~cm}^{2}$. These data indicate that most carcasses carrying STEC do so at quite low levels.

\subsection{What constitutes a virulent STEC?}

The ability to cause disease is more than likely not solely dependent on the expression of the Shiga toxins. STEC capable of expressing Shiga toxins have been isolated from asymptomatic individuals; therefore, multiple factors must play roles in causing disease, such as additional virulence factors, ingested dose, and immune status of the individual (Acheson, 2000; Gyles et al., 1998; Nataro \& Kaper, 1998). Differences have been identified in strains that are predominantly isolated from cattle as compared to those from human clinical cases. It has been shown that st $x 1$ more often is associated with bovine isolates, while st $x 2$ more often is associated with human isolates (Boerlin et al., 1999). Also, several studies identified bovine isolates as less likely to carry the additional virulence factors intimin (eae) and EHEC-hemolysin (hlyA) when compared to human isolates (Arthur et al., 2002; Boerlin et al., 1999; Johnson et al., 1996). Arthur et al. (2002) characterized over 300 non-O157 STEC strains isolated from cattle carcasses during slaughter. The vast majority $(72 \%)$ of those strains only harbored st $x$ genes and not the additional virulence factor genes for intimin or EHEC-hemolysin (Arthur et al., 2002). However, when Johnson et al. (1996) compared toxin type and the presence of eae and hly $A$ between bovine-related strains and human strains of the same serotypes, they found the two populations to be very similar. One interpretation of this data would be that highly virulent strains of STEC are present in cattle but are a minority in the population. The larger number of isolates may consist mostly of STEC strains that lack additional virulence factors, that is, eae and $h l y A$, and are potentially less virulent.
In summary, non-O157 STEC can cause severe disease and are commonly found colonizing cattle and contaminating beef carcasses. While the majority of the bovine-related STEC lack accessory virulence factors, $28 \%$ of strains have the same serotypes and virulence genotypes as those which cause human disease. Until methods are available to distinguish between pathogenic and non-pathogenic STEC, all STEC will have to be treated as potential sources of foodborne illness.

\section{Salmonella}

Salmonellosis is the most common foodborne illness in the United States. An estimated 1.4 million cases occur annually in the United States; of these, approximately 30,000 are culture-confirmed cases reported to the CDC (CDC, National Center for Infectious Diseases, 2003). Two thousand serotypes of Salmonella are believed to cause human disease, but the majority of disease cases are caused by just five serotypes. Several food items, including a variety of beef products, have been implicated in Salmonellosis disease outbreaks.

Salmonella have been routinely detected in cattle feces. Barkocy-Gallagher et al. (2003) sampled fed beef cattle presented for slaughter and found that over the course of one year the fecal prevalence ranged from $2.1 \%$ to $9.1 \%$. This range was very similar to that obtained in the USDA's National Animal Health Monitoring System (NAHMS) Feedlot '99 study where Salmonella fecal prevalence varied from $2.8 \%$ to $11.2 \%$ for feedlot cattle, with the peak prevalence occurring in the summer months (USDA, APHIS, 2001). US dairy cattle have been shown to have a similar fecal prevalence (7.4\% of 3669 samples) of Salmonella as fed cattle (USDA, APHIS, 2003).

Salmonella have been found on the hides of fed beef cattle at higher rates than in feces. We found hide prevalence to vary from $27.7 \%$ in the winter to $91.6 \%$ and $97.7 \%$ in the summer and fall, respectively (BarkocyGallagher et al., 2003). Rivera-Betancourt et al. (2004) also found fed beef cattle to have a high hide prevalence of Salmonella with a range of $50.3 \%$ to $91.8 \%$ between two processing plants.

Carcass contamination with Salmonella immediately after hide removal and prior to any antimicrobial interventions has been reported to range from 3\% to $24.9 \%$ over the course of a year for fed beef (Barkocy-Gallagher et al., 2003). Similar levels $(\sim 25 \%)$ were reported for fed beef carcasses sampled at two geographically distant processing plants (Rivera-Betancourt et al., 2004). After the full complement of all antimicrobial interventions, Salmonella prevalence was very low (Barkocy-Gallagher et al., 2003; Rivera-Betancourt et al., 2004). 
Similar to E. coli $\mathrm{O} 157: \mathrm{H} 7$ contamination, fecal prevalence for non-O157 STEC and Salmonella is usually reported to be less than that of carcass prevalence and cannot account for the high rates of contamination. Conversely, hide prevalence for these pathogens is generally in excess of carcass contamination rates. Additionally, the rates of carcass contamination are highest immediately after hide removal and consistently decline during processing as antimicrobial interventions are applied. These facts led to the belief that the hide is the major source of carcass contamination and that antimicrobial interventions should target microbes present on the hide as the animal enters the slaughter facility.

\section{Interventions}

\subsection{Hide interventions}

The evidence leading to the conclusion that the hides of cattle presented for slaughter are the primary source of pathogens that contaminate beef carcasses has already been described. Based on this evidence, effective decontamination of the hide should result in less contamination of the carcass following hide removal.

\subsubsection{Chemical dehairing}

The potential of chemical dehairing was first evaluated by Schnell et al. (1995). They reported that the dehairing process resulted in visually cleaner carcasses and reduced the requirement for trimming to meet the zero tolerance policy on fecal contamination. However, they (Schnell et al., 1995) found that the dehairing process did not significantly reduce the bacterial load on carcasses (perhaps because of a low number of observations). In contrast, Castillo et al. (Castillo, Dickson, Clayton, Lucia, \& Acuff, 1998) found that a chemical dehairing process significantly reduced the counts of aerobic bacteria, coliforms, and E. coli, as well as artificially inoculated Salmonella typhimurium and E. coli O157:H7 strains on hide pieces. However, their study (Castillo et al., 1998) did not address the key concern: the potential transfer of bacteria, especially pathogens, from the hide to the carcass during hide removal. The best evidence of the effectiveness of chemical dehairing as a hide intervention in a commercial operation for preventing carcass contamination was obtained by Nou et al. (2003). That data demonstrated that chemical dehairing of cattle hides was an effective intervention to reduce the incidence of hide-to-carcass contamination with pathogens. The data also implied that any effective hide intervention process incorporated into beef processing procedures would significantly reduce carcass contamination by E. coli $\mathrm{O} 157: \mathrm{H} 7$.

\subsubsection{Cetylpyridinium chloride}

Although chemical dehairing was an effective hide intervention, industry did not consider it to be feasible to implement. Thus, we identified cetylpyridinium chloride (CPC) as an alternative hide intervention that should be evaluated. CPC is a common oral antimicrobial (Pitten \& Kramer, 2001) and has been described by Slavik and coworkers (Kim \& Slavik, 1996; Xiong, Li, Slavik, \& Walker, 1998; Yang, Li, \& Slavik, 1998) for use in decontamination of chicken carcasses in the poultry industry. Experiments that applied CPC to beef focused on the decontamination of carcasses (Cutter et al., 2000) and trim before grinding (Pohlman, Stivarius, McElyea, \& Waldroup, 2002b) rather than on the decontamination of hides prior to removal. We first reported a series of experiments designed to determine the optimal application of CPC as a hide intervention (Bosilevac et al., 2004c). Those results indicated that, under the proper conditions, CPC treatment was effective at reducing microbial populations on cattle hides. Additionally, the results established the parameters needed to develop a protocol to test whether a $1 \%$ CPC hide intervention process would reduce microbial contamination of the carcass by bacteria from the hide during processing.

Bosilevac et al. (2004a) tested the potential of a combined water wash and CPC treatment as a hide intervention under conditions simulating a hide wash cabinet. Pre-evisceration carcass APC and EBC were reduced in the CPC treatment group, and the prevalence of $E$. coli $\mathrm{O} 157$ on hides was greatly reduced, resulting in near elimination of the pathogen from pre-evisceration carcasses. It was concluded that water washing followed by an antimicrobial treatment, such as CPC, held great potential as an effective hide intervention step and should be further evaluated for implementation as an antimicrobial compound in a hide wash cabinet after stunning and before hide removal (Bosilevac et al., 2004a).

\subsubsection{Other antimicrobial compounds and vacuuming}

Other antimicrobial compounds approved for use in processing plants were evaluated for efficacy when used as a hide intervention (Bosilevac, Nou, Osborn, Allen, \& Koohmaraie, 2005a) in order to provide processors with data on possible alternatives to chemical dehairing and CPC. Compounds tested were $1.6 \%$ sodium hydroxide, $4 \%$ trisodium phosphate, $4 \%$ chlorofoam, or $4 \%$ phosphoric acid, and each was followed by a rinse step using either water or acidified chlorine at 200 or $500 \mathrm{ppm}$. Additionally, a vacuuming step after the rinse was incorporated to alleviate concerns of excess liquid running from the hide to the exposed carcass during the initial steps of removal. The use of a common processing plant steam vacuum was investigated to determine if removing 
the excess liquids interfered with or improved the effects of hide washing.

Phosphoric acid, sodium hydroxide, and chlorofoam were all more effective than trisodium phosphate, regardless of rinse compounds or vacuuming as a final step (Bosilevac et al., 2005a). Phosphoric acid was the most effective wash compound and $500 \mathrm{ppm}$ acidified chlorine was the most effective rinse treatment. Vacuuming of the treated areas to remove excess liquid further improved hide cleanliness.

\subsubsection{On-line hide washing cabinets}

Our research on hide interventions (Bosilevac et al., 2004a, 2004c, 2005a; Nou et al., 2003) formed the basis for the development of effective hide washing systems now installed in all Cargill Meat Solutions (formerly Excel Corp.) beef processing plants. Cargill's choice of compounds to use in the automated hide wash cabinet involved consideration of cost, ease of implementation, and efficacy. Based on this combination of factors a recirculating wash cabinet system was designed and installed at a processing plant. Hides were washed after cattle were stunned and exsanguinated, and before any other portion of the hide was opened. Sodium hydroxide at $1.5 \%$ was chosen as the wash because it does not lose activity, as acids frequently do, in a recirculating system (Bosilevac et al., 2005a). Chlorine at $1 \mathrm{ppm}$ was used to clean the recirculated water used for the rinse step and was not intended to have an additional antimicrobial effect on the hides. As each animal exited the cabinet, plant personnel used a steam vacuum to remove excess liquid and loosened material along the hide opening pattern lines.

The effectiveness of cleaning the hide with a hide wash cabinet was evaluated by measuring its effects on hides and the subsequent corresponding pre-evisceration carcasses (Bosilevac et al., 2005a). Hides were sampled before entering and after exiting the cabinet. The prevalence of $E$. coli $\mathrm{O} 157$ was greatly reduced on hides (from $44 \%$ to $17 \%$ ) and on pre-evisceration carcasses (from $17 \%$ to $2 \%$ ) when the cabinet was in use. These results support decontamination of hides as an effective means to reduce pathogen contamination of cattle carcasses during processing.

\subsubsection{Ozonated and electrolyzed oxidizing (EO) waters}

Because we believe that hide interventions currently are the most effective means to reduce pathogens on beef, our research has been aimed at providing as many viable alternatives as possible to increase the rate and ease of implementation of hide interventions by all processors. The latest of these are ozonated water and EO water (Bosilevac, Shackelford, Brichta, \& Koohmaraie, $2005 \mathrm{~b}$ ), both of which possess strong oxidation-reduction potential. Both ozonated and EO waters were evaluated using a hide washing system to determine their efficacy as potential hide interventions (Bosilevac et al., 2005b). The prevalence of E. coli $\mathrm{O} 157$ on hides was reduced from $89 \%$ to $31 \%$ following treatment with ozonated water, and from $82 \%$ to $35 \%$ following EO water treatment. The results suggested that on-line implementation of processes using either ozonated or EO water will have similar effectiveness as previously described hide interventions in controlling pathogens on carcasses.

\subsection{Carcass interventions}

\subsubsection{Steam vacuuming}

The regulatory aftermath of the E. coli $\mathrm{O} 157: \mathrm{H} 7$ outbreak in 1993 resulted in substantial efforts by the beef processing industry to improve the microbiological quality of beef carcasses. Zero tolerance for fecal contamination led to excessive knife trimming of carcasses with the concomitant effect of substantial carcass weight loss. We pioneered steam vacuuming as an alternative to knife trimming that effectively removes visible contamination without the associated product loss (Dorsa, 1997; Dorsa, Cutter, \& Siragusa, 1997; Dorsa, Cutter, Siragusa, \& Koohmaraie, 1996). Steam vacuuming has been implemented in nearly all beef processing plants at multiple stages in the harvesting process.

In the processing plant, knife trimming and steam vacuuming can produce bacterial reductions in localized areas and are useful for pathogen reduction of visibly contaminated sites and carcass regions believed to be "hot spots" (hide removal pattern lines). These techniques, however, cannot be used efficiently for the entire carcass (Dorsa et al., 1997).

\subsubsection{Organic acids and hot water}

Whole carcass spray washing has continually improved over time. Washing has evolved from ambient to warm water washes to use of antimicrobials, hot water, and steam. Numerous studies have evaluated the efficacy of a variety of organic acids for sanitizing whole carcass sides (Dickson \& Anderson, 1992; Dorsa, 1997; Siragusa, 1995). Lactic acid has become the most commonly used organic acid in commercial practice. We determined that hot water was an effective carcass intervention (Dorsa et al., 1996, 1997). In addition, many processors have implemented lactic acid washes on pre-evisceration carcasses. Because of the effectiveness of hot water, we evaluated its use compared to lactic acid as a pre-evisceration wash (Bosilevac, Nou, Barkocy-Gallagher, Arthur, \& Koohmaraie, unpublished data). Hot water reduced E. coli $\mathrm{O} 157$ prevalence by $81 \%$ and lactic acid reduced E. coli $\mathrm{O} 157$ prevalence by $35 \%$, while the combination of the two produced results no greater (a 79\% reduction) than hot water alone. These results show that the main effects of decontaminating pre-evisceration carcasses occur with the use of 
hot water, as the reductions were not increased by lactic acid treatment alone or in combination with hot water treatment. If situations present a choice of implementing either hot water or lactic acid at a processing point, the data indicate that using hot water would be more beneficial. However, hot water only works if proper temperature is maintained to get $74{ }^{\circ} \mathrm{C}$ on the carcass surface for $>5 \mathrm{~s}$.

Dorsa et al. (1996) demonstrated that steam was effective for carcass decontamination. Cargill Meat Solutions (formerly Excel Corp.) and Frigoscandia subsequently developed commercial steam pasteurization cabinets (Nutsch et al., 1997; Phebus et al., 1997) that Cargill Meat Solutions has installed in all of its plants.

\subsection{3. "Multiple hurdle" carcass interventions}

Because none of the interventions are $100 \%$ effective, all beef processors now utilize a "multiple-hurdle" intervention system of sequential interventions at various processing steps to ensure the safety of their products (Bacon et al., 2000). Steam vacuuming that achieves significant reduction of bacteria on beef surfaces by targeting areas contacted by knives or machines during the skinning process (hide opening pattern lines) can be followed with a pre-evisceration wash of hot water or organic acid that further eliminates pathogens. After evisceration and splitting, carcasses pass through a thermal pasteurization chamber, where heated water $\left(74{ }^{\circ} \mathrm{C}\right)$ or steam is applied. This treatment is lethal to bacteria on the carcass surface and further cleanses the carcass. Finally, a heated organic acid or acidified chlorine rinse is applied before carcasses enter the hotbox (or final sales cooler).

In addition to the direct intervention measures, many processors have instituted good manufacturing practices and changes in their processing facilities to improve beef safety. Changes such as increased spacing between carcasses to reduce cross contamination, improved lighting to reveal contaminants, positive pressure ventilation systems, use of two knives on the slaughter/skinning lines (one in use and one sitting in a sterilizer) and maintenance of ambient air temperatures as low as possible have been implemented.

Recent studies have evaluated the effectiveness of sequential, multiple hurdle intervention systems to improve beef safety (Arthur et al., 2004; Bacon et al., 2000). Results validated that sequential multiple hurdle interventions reduce bacteria on beef carcasses better than any one intervention alone. Recontamination could occur after evisceration and splitting, but the effect was countered by subsequent use of steam pasteurization and organic acid washes that ultimately reduced bacteria to levels below that detected at any other step of the process.

\subsubsection{Low-dose, low-penetrating radiation (electron} beam)

Ionizing radiation has been approved for use in treating refrigerated or frozen uncooked meat, meat byproducts, and certain other meat food products to reduce levels of foodborne pathogens and to extend shelf-life (USDA, FSIS, 1999; US FDA, 1997). The effectiveness of radiation for eliminating bacteria from meat is well established. Traditionally this has been done by irradiating large lots of either non-intact cuts or ground beef. Recently, low-dose/low-penetration electron beam (Ebeam) irradiation technology has evolved to the point where large non-uniform surface areas can be effectively treated (for example, an entire carcass side). This allows whole carcasses to be treated after chilling. In such a process only the surface (approximately $15 \mathrm{~mm}$ of penetration) of each carcass side receives a significant radiation dose. Because pathogen contamination of carcasses is a surface phenomenon, this treatment would be expected to dramatically lower the pathogen load without adversely affecting the organoleptic qualities of products made from the carcasses.

It has been shown that an E-beam radiation dose of approximately $1 \mathrm{kGy}$ with a depth penetration of $15 \mathrm{~mm}$ reduced stationary phase $E$. coli $\mathrm{O} 157: \mathrm{H} 7$ on the surface of beef tissue by at least $4 \log \mathrm{CFU} / \mathrm{cm}^{2}$ with acceptable effects on organoleptic properties (Arthur et al., 2005b). Levels of $E$. coli O157:H7 contamination on beef carcasses following conventional multi-hurdle antimicrobial interventions are low. Barkocy-Gallagher et al. (2003) showed that beef carcasses from several major processing plants had E. coli O157:H7 levels of $<3$ CFU/100- $\mathrm{cm}^{2}$ following the full complement of antimicrobial interventions. Such levels of contamination could easily be eliminated using low-dose, low-penetration E-beam technology. Low-dose, low-penetration Ebeam irradiation has great potential as an additional antimicrobial intervention in beef processing, immediately before fabrication.

\subsection{Trim interventions}

\subsubsection{Combination treatments}

Antimicrobial interventions have been focused on either carcasses or hides. Because boneless beef trim is the raw material for ground beef, interventions that target boneless beef trim before grinding may be a practical point of treatment because this is the last stage of processing before grinding (Kang, Koohmaraie, Dorsa, \& Siragusa, 2001a; Pohlman, Stivarius, McElyea, Johnson, \& Johnson, 2002a; Ransom et al., 2003). To our knowledge, there has been no commercial implementation of trim interventions, however, a number of potential trim interventions have been evaluated.

A multiple-hurdle antimicrobial process for beef trim was developed and evaluated (Kang et al., 2001a; Kang, 
Koohmaraie, \& Siragusa, 2001b). Treatments included various combinations of multiple water washes, lactic acid $(2 \%)$ applied at various temperatures, hot (65 and $\left.82^{\circ} \mathrm{C}\right)$ water sprays, and hot $\left(510^{\circ} \mathrm{C}\right)$ air. All sample treatments involving lactic acid resulted in continuously decreasing microbial populations during refrigerated storage. Based on microbial reduction and quality aspects, it was concluded that successively applied combination antimicrobial treatments for beef trim offer potential food safety benefits.

\subsubsection{Acidified sodium chlorite}

Acidified sodium chlorite (ASC) is a compound that has been used as a broad-spectrum disinfectant. Interventions that used ASC to effectively reduce contamination of poultry (Kemp, Aldrich, Guerra, \& Schneider, 2001; Kemp, Aldrich, \& Waldroup, 2000) and beef products (Castillo, Lucia, Kemp, \& Acuff, 1999; Rourke et al., 2001) have been described. Beginning in 1996, the US Food and Drug Administration (FDA) approved ASC as a secondary direct food additive permitted in food for human consumption to reduce pathogens and extend shelf life of poultry, red meats, seafood, and other raw agricultural commodities (US FDA, 2003). The FDA-approved concentration for use in the processing of red meat, red meat parts, and organs was stated to be $500-1200 \mathrm{ppm}$ prepared at a final $\mathrm{pH}$ of 2.5-2.9. Concentrations of ASC used to reduce pathogens on beef trimmings before grinding have been reported at $1000-1200 \mathrm{ppm}$ applied at rates of $1-3 \mathrm{oz} / \mathrm{lb}$ (Castillo et al., 1999; Rourke et al., 2001). Although ASC has been shown to be effective at reducing pathogen contamination of beef trim when used at these dosages, the ground beef produced from trim treated at these levels can be discolored and have an off taste (Bosilevac, Shackelford, Fahle, Biela, \& Koohmaraie, 2004b). Therefore, decreased dosages of ASC were investigated to determine if satisfactory microbial reductions and desirable consumer qualities of odor, color, and taste could be maintained (Bosilevac et al., 2004b).

The results of this study indicated that decreased dosages of ASC reduce contamination and lengthen the shelf life of ground beef. Furthermore, the $300 \mathrm{ppm}$ ASC treatment reduced bacterial counts while maintaining desirable organoleptic qualities of the ground beef. Our results found ASC treatments typically caused reductions of APC and EBC that were twofold greater than those reported for other single-step interventions, and as effective as any combination treatment, on trim before grinding.

\section{Test-and-hold process}

In spite of significant investment in research by the meat industry and the government and implementation of many new interventions by beef processing plants, E. coli $\mathrm{O} 157: \mathrm{H} 7$ continued to present a challenge and outbreaks associated with improperly cooked ground beef continued to occur in the 1990s. Beginning with the late 1990s, the meat industry began to implement a process called test-and-hold. A processor samples the trim (the raw material used to make ground beef) or ground beef and tests the sample for the presence of E. coli $\mathrm{O} 157: \mathrm{H} 7$. The product does not enter into commerce unless the sample is found to be negative for $E$. coli $\mathrm{O} 157: \mathrm{H} 7$. This is an extremely expensive practice for the industry, costing tens of millions of dollars. Test-and-hold in conjunction with other practices has been extremely effective as judged by the dramatic reduction in the number of samples testing positive for E. coli $\mathrm{O} 157: \mathrm{H} 7$ in the USDA-FSIS verification program. This process serves as insurance for both beef processors and their customers. But, the ultimate beneficiary is the consumer.

An effective test-and-hold program has an absolute dependency on highly accurate methods of testing ground beef for E. coli $\mathrm{O} 157: \mathrm{H} 7$. Optimization of three testing attributes, detection time, specificity, and sensitivity, are critical to the success of such programs. Because ground beef is a highly perishable product, the testing methodology used must be as rapid as possible (turn-around time of about 8-12 h). Also, the test must have as low a level of false positives as possible so product is not needlessly discarded. Excessive false positives will make the process far more expensive. Finally, false negatives cannot be tolerated. False negative results would allow contaminated product to be released and potentially cause disease, thereby defeating the whole purpose of the test-and-hold process. Recently we studied commercially developed methods for detecting $E$. coli $\mathrm{O} 157: \mathrm{H} 7$ in ground beef for their abilities to meet the above criteria (Arthur, Bosilevac, Nou, \& Koohmaraie, 2005a).

\section{Pre-harvest versus post-harvest interventions}

From time to time there are major debates among scientists in the field with respect to the best points at which to apply interventions. Obviously, since live cattle are the source of E. coli $\mathrm{O} 157: \mathrm{H} 7$, it would be very advantageous to present the cattle for slaughter in an E. coli $\mathrm{O} 157: \mathrm{H} 7$-free status. But, is this possible? To determine how the best return on investment can be achieved for any given intervention one would have to examine the entire production chain. Since beef production is a highly fragmented industry and since the development and implementation of any new intervention is very costly, there is a tendency for each segment of the industry to want the segment before it to make sure cattle are free of $E$. coli $\mathrm{O} 157: \mathrm{H} 7$. But to answer the 
question one will have to assume a fully integrated cattle production system and then determine the most effective steps for introduction of new interventions. We propose that harvest is the most logical and effective step in the beef production system at which to maximally reduce E. coli $\mathrm{O} 157: \mathrm{H} 7$ (as well as other pathogens) on cattle and, thereby, in ground beef. We have arrived at this conclusion for a number of reasons. Pre-harvest interventions are specific for particular pathogens, may lead to the development of resistance, and not one has as yet been shown to be effective, whereas post-harvest interventions are non-specific (e.g., heat kills most pathogens), they do not lead to the development of resistance, and most are extremely effective. A key issue in the battle against E. coli $\mathrm{O} 157: \mathrm{H} 7$ is the equitable sharing of intervention costs. It does not seem logical for the processing segment to shoulder the entire cost just because it operates in the most effective and economical production step for controlling E. coli O157:H7. Some method of sharing some of those costs should be feasible and would be good for the entire industry.

\section{Summary}

The 1993 outbreak of E. coli O157:H7 began an era of intensive effort to improve the microbiological quality of beef. The designation of E. coli $\mathrm{O} 157: \mathrm{H} 7$ as an adulterant in ground beef is perhaps the reason for the intensive effort to rid ground beef of E. coli $\mathrm{O} 157: \mathrm{H} 7$. When E. coli $\mathrm{O} 157: \mathrm{H} 7$ was declared an adulterant, it was thought that the prevalence of E. coli $\mathrm{O} 157: \mathrm{H} 7$ was less than $1 \%$ in cattle presented for harvest. With dramatic improvement in the ability to isolate and detect $E$. coli O157:H7, we now know that the prevalence of $E$. coli O157:H7 on cattle hides during the spring, summer, and fall is greater than $50 \%$, and $100 \%$ prevalence is not unusual. Because of such a high prevalence rate, E. coli $\mathrm{O} 157: \mathrm{H} 7$ remains a challenge, in spite of years of effort and billions of dollars invested in research and upgrading of the harvest plants. To protect their customers as well as their businesses, albeit at a great cost, US beef processing plants have implemented the test-and-hold process. The test-and-hold process in conjunction with other practices has resulted in a dramatic reduction in the incidence of $E$. coli $\mathrm{O} 157: \mathrm{H} 7$ in ground beef as well as in E. coli $\mathrm{O} 157: \mathrm{H} 7$ related human illnesses. However, because the primary source of $E$. coli $\mathrm{O} 157: \mathrm{H} 7$ is the cattle hide, E. coli $\mathrm{O} 157: \mathrm{H} 7$ is only found on the surface of the beef carcass, and in spite of all efforts $E$. coli $\mathrm{O} 157: \mathrm{H} 7$ continues to be a challenge, perhaps an effective intervention could be low-dose, low penetrating E-beam irradiation of beef carcasses prior to fabrication. Over a decade of intensive effort by the public and private sector has resulted in dramatic improvements such that the year 2010 national health objectives for E. coli $\mathrm{O} 157: \mathrm{H} 7$ were almost achieved by 2003 . To maximize the benefit for the public and private sectors, food handlers and consumers also must do their part. Therefore, education of people involved in food handling and preparation is an area that needs attention and would pay great dividends towards ensuring the safety of our food supply.

\section{References}

Acheson, D. W. (2000). How does Escherichia coli O157:H7 testing in meat compare with what we are seeing clinically? Journal of Food Protection, 63, 819-821.

Arthur, T. M., Barkocy-Gallagher, G. A., Rivera-Betancourt, M., \& Koohmaraie, M. (2002). Prevalence and characterization of nonO157 Shiga toxin-producing Escherichia coli on carcasses in commercial beef cattle processing plants. Applied and Environmental Microbiology, 68, 4847-4852.

Arthur, T. M., Bosilevac, J. M., Nou, X., \& Koohmaraie, M. (2005a). Evaluation of culture- and PCR-based detection methods for Escherichia coli $\mathrm{O} 157$ in ground beef. Journal of Food Protection (in press).

Arthur, T. M., Bosilevac, J. M., Nou, X., Shackelford, S. D., Wheeler, T. L., Kent, M. P., et al. (2004). Escherichia coli O157 prevalence and enumeration of aerobic bacteria, Enterobacteriaceae, and Escherichia coli $\mathrm{O} 157$ at various steps in commercial beef processing plants. Journal of Food Protection, 67, 658-665.

Arthur, T. M., Wheeler, T. L., Shackelford, S. D., Bosilevac, J. M., Nou, X., \& Koohmaraie, M. (2005b). Effects of low-dose, lowpenetration electron beam irradiation of chilled beef carcass surface cuts on meat safety and meat quality. Journal of Food Protection, 68, 666-672.

Bacon, R. T., Belk, K. E., Sofos, J. N., Clayton, R. P., Reagan, J. O., \& Smith, G. C. (2000). Microbial populations on animal hides and beef carcasses at different stages of slaughter in plants employing multiple-sequential interventions for decontamination. Journal of Food Protection, 63, 1080-1086.

Barkocy-Gallagher, G. A., Arthur, T. M., Rivera-Betancourt, M., Nou, X., Shackelford, S. D., Wheeler, T. L., et al. (2003). Seasonal prevalence of Shiga toxin-producing Escherichia coli, including O157:H7 and non-O157 serotypes, and Salmonella in commercial beef processing plants. Journal of Food Protection, 66, 1978-1986.

Barkocy-Gallagher, G. A., Arthur, T. M., Siragusa, G. R., Keen, J. E., Elder, R. O., Laegreid, W. W., et al. (2001). Genotypic analyses of Escherichia coli $\mathrm{O} 157: \mathrm{H} 7$ and O157 nonmotile isolates recovered from beef cattle and carcasses at processing plants in the Midwestern states of the United States. Applied and Environmental Microbiology, 67, 3810-3818.

Barkocy-Gallagher, G. A., Berry, E. D., Rivera-Betancourt, M., Arthur, T. M., Nou, X., \& Koohmaraie, M. (2002). Development of methods for the recovery of Escherichia coli O157:H7 and Salmonella from beef carcass sponge samples and bovine fecal and hide samples. Journal of Food Protection, 65, 1527-1534.

Bell, B. P., Griffin, P. M., Lozano, P., Christie, D. L., Kobayashi, J. M., \& Tarr, P. I. (1997). Predictors of hemolytic uremic syndrome in children during a large outbreak of Escherichia coli O157:H7 infections. Pediatrics, 100, E12.

Bettelheim, K. A. (2000). Role of non-O157 VTEC. Journal of Applied Microbiology, 88(Suppl.), 38S-50S.

Blanco, M., Blanco, J. E., Blanco, J., Mora, A., Prado, C., Alonso, M. P., et al. (1997). Distribution and characterization of faecal verotoxin-producing Escherichia coli (VTEC) isolated from healthy cattle. Veterinary Microbiology, 54, 309-319. 
Boerlin, P., McEwen, S. A., Boerlin-Petzold, F., Wilson, J. B., Johnson, R. P., \& Gyles, C. L. (1999). Associations between virulence factors of Shiga toxin-producing Escherichia coli and disease in humans. Journal of Clinical Microbiology, 37, 497-503.

Bosilevac, J. M., Arthur, T. M., Wheeler, T. L., Shackelford, S. D., Rossman, M., Reagan, J. O., et al. (2004a). Prevalence of Escherichia coli $\mathrm{O} 157$ and levels of aerobic bacteria and Enterobacteriaceae are reduced when hides are washed and treated with cetylpyridinium chloride at a commercial beef processing plant. Journal of Food Protection, 67, 646-650.

Bosilevac, J. M., Nou, X., Osborn, M. S., Allen, D. M., \& Koohmaraie, M. (2005a). Development and evaluation of an online hide decontamination procedure for use in a commercial beef processing plant. Journal of Food Protection, 68, 265-272.

Bosilevac, J. M., Shackelford, S. D., Brichta, D. M., \& Koohmaraie, M. (2005b). Efficacy of ozonated and electrolyzed oxidative waters to decontaminate hides of cattle before slaughter. Journal of Food Protection (in press).

Bosilevac, J. M., Shackelford, S. D., Fahle, R., Biela, T., \& Koohmaraie, M. (2004b). Decreased dosage of acidified sodium chlorite reduces microbial contamination and maintains organoleptic qualities of ground beef products. Journal of Food Protection, 67, 2248-2254.

Bosilevac, J. M., Wheeler, T. L., Rivera-Betancourt, M., Nou, X., Arthur, T. M., Shackelford, S. D., et al. (2004c). Protocol for evaluating the efficacy of cetylpyridinium chloride as a beef hide intervention. Journal of Food Protection, 67, 303-309.

Castillo, A., Dickson, J. S., Clayton, R. P., Lucia, L. M., \& Acuff, G. R. (1998). Chemical dehairing of bovine skin to reduce pathogenic bacteria and bacteria of fecal origin. Journal of Food Protection, 61, 623-625.

Castillo, A., Lucia, L. M., Kemp, G. K., \& Acuff, G. R. (1999). Reduction of Escherichia coli O157:H7 and Salmonella typhimurium on beef carcass surfaces using acidified sodium chlorite. Journal of Food Protection, 62, 580-584.

Centers for Disease Control and Prevention (2000). Escherichia coli O111:H8 outbreak among teenage campers - Texas, 1999. Morbidity and Mortality Weekly Report, 49, 321-324.

Centers for Disease Control and Prevention (2004). Preliminary FoodNet data on the incidence of infection with pathogens transmitted commonly through food - selected sites, United States, 2003. Morbidity and Mortality Weekly Report, 53, 338-343.

Centers for Disease Control and Prevention, National Center for Infectious Diseases (2003). Salmonellosis technical information. Available fromhttp://www.cdc.gov/ncidod/dbmd/diseaseinfo/salmonellosis_t.htm .

Chapman, P. A., Siddons, C. A., Wright, D. J., Norman, P., Fox, J., \& Crick, E. (1993). Cattle as a possible source of verocytotoxinproducing Escherichia coli $\mathrm{O} 157$ infections in man. Epidemiology and Infection, 111, 439-447.

Cray, W. C., Jr., Thomas, L. A., Schneider, R. A., \& Moon, H. W. (1996). Virulence attributes of Escherichia coli isolated from dairy heifer feces. Veterinary Microbiology, 53, 369-374.

Cutter, C. N., Dorsa, W. J., Handie, A., Rodriguez-Morales, S., Zhou, X., Breen, P. J., et al. (2000). Antimicrobial activity of cetylpyridinium chloride washes against pathogenic bacteria on beef surfaces. Journal of Food Protection, 63, 593-600.

Dickson, J. S., \& Anderson, M. E. (1992). Microbiological decontamination of food animal carcasses by washing and sanitizing systems: A review. Journal of Food Protection, 55, 133-140.

Dorsa, W. J. (1997). New and established carcass decontamination procedures commonly used in the beef-processing industry. Journal of Food Protection, 60, 1146-1151.

Dorsa, W. J., Cutter, C. N., \& Siragusa, G. R. (1997). Effects of steamvacuuming and hot water spray wash on the microflora of refrigerated beef carcass surface tissue inoculated with Escherichia coli $\mathrm{O} 157: \mathrm{H} 7$, Listeria innocua, and Clostridium sporogenes. Journal of Food Protection, 60, 114-119.

Dorsa, W. J., Cutter, C. N., Siragusa, G. R., \& Koohmaraie, M. (1996). Microbial decontamination of beef and sheep carcasses by steam, hot water spray washes, and a steam-vacuum sanitizer. Journal of Food Protection, 60, 127-135.

Elder, R. O., Keen, J. E., Siragusa, G. R., Barkocy-Gallagher, G. A., Koohmaraie, M., \& Laegreid, W. W. (2000). Correlation of enterohemorrhagic Escherichia coli $\mathrm{O} 157$ prevalence in feces, hides, and carcasses of beef cattle during processing. Proceedings of the National Academy of Sciences of the United States of America, 97, 2999-3003.

Feng, P., Weagant, S. D., \& Monday, S. R. (2001). Genetic analysis for virulence factors in Escherichia coli $\mathrm{O} 104: \mathrm{H} 21$ that was implicated in an outbreak of hemorrhagic colitis. Journal of Clinical Microbiology, 39, 24-28

Fey, P. D., Wickert, R. S., Rupp, M. E., Safranek, T. J., \& Hinrichs, S. H. (2000). Prevalence of non-O157:H7 Shiga toxin-producing Escherichia coli in diarrheal stool samples from Nebraska. Emerging Infectious Diseases, 6, 530-533.

Griffin, P. M., Mead, P. S., Van Gilder, T., Hunte, S. B., \& Strockbine, N. A. (2001). Epidemiology of Shiga toxin-producing E. coli infections in the United States: update, successes, and challenges. Conference on epidemiology of VTEC and workshop on 'Typing Methods for VTEC Strains,' 8-10 February 2001, Malahide, Ireland

Gyles, C., Johnson, R., Gao, A., Ziebell, K., Pierard, D., Aleksic, S., et al. (1998). Association of enterohemorrhagic Escherichia coli hemolysin with serotypes of Shiga-like-toxin-producing Escherichia coli of human and bovine origins. Applied and Environmental Microbiology, 64, 4134-4141.

Hancock, D., Besser, T., Lejeune, J., Davis, M., \& Rice, D. (2001). The control of VTEC in the animal reservoir. International Journal of Food Microbiology, 66, 71-78.

Johnson, R. P., Clarke, R. C., Wilson, J. B., Read, S. C., Rahn, K., Renwick, S. A., et al. (1996). Growing concerns and recent outbreaks involving non-O157:H7 serotypes of verotoxigenic Escherichia coli. Journal of Food Protection, 59, 1112-1122.

Johnson, W. M., Lior, H., \& Bezanson, G. S. (1983). Cytotoxic Escherichia coli $\mathrm{O} 157: \mathrm{H} 7$ associated with haemorrhagic colitis in Canada. Lancet, 76, 8314-8315.

Kang, D. H., Koohmaraie, M., Dorsa, W. J., \& Siragusa, G. R. (2001a). Development of a multiple-step process for the microbial decontamination of beef trim. Journal of Food Protection, 64, 63-71.

Kang, D. H., Koohmaraie, M., \& Siragusa, G. R. (2001b). Application of multiple antimicrobial interventions for microbial decontamination of commercial beef trim. Journal of Food Protection, 64, $168-171$.

Kemp, G. K., Aldrich, M. L., Guerra, M. L., \& Schneider, K. R. (2001). Continuous online processing of fecal- and ingestacontaminated poultry carcasses using an acidified sodium chlorite antimicrobial intervention. Journal of Food Protection, 64, 807-812.

Kemp, G. K., Aldrich, M. L., \& Waldroup, A. L. (2000). Acidified sodium chlorite antimicrobial treatment of broiler carcasses. Journal of Food Protection, 63, 1087-1092.

Kim, J. W., \& Slavik, M. F. (1996). Cetylpyridinium chloride (CPC) treatment on poultry skin to reduce attached Salmonella. Journal of Food Protection, 59, 322-326.

Kobayashi, H., Shimada, J., Nakazawa, M., Morozumi, T., Pohjanvirta, T., Pelkonen, S., et al. (2001). Prevalence and characteristics of Shiga toxin-producing Escherichia coli from healthy cattle in Japan. Applied and Environmental Microbiology, 67, 484-489.

Leung, P. H., Yam, W. C., Ng, W. W., \& Peiris, J. S. (2001). The prevalence and characterization of verotoxin-producing Esche- 
richia coli isolated from cattle and pigs in an abattoir in Hong Kong. Epidemiology and Infection, 126, 173-179.

McCarthy, T. A., Barrett, N. L., Hadler, J. L., Salsbury, B., Howard, R. T., Dingman, D. W., et al. (2001). Hemolytic-uremic syndrome and Escherichia coli $\mathrm{O} 121$ at a lake in Connecticut 1999. Pediatrics, 108, E59.

Mead, P. S., Slutsker, L., Dietz, V., McCaig, L. F., Bresee, J. S., Shapiro, C., et al. (1999). Food-related illness and death in the United States. Emerging Infectious Diseases, 5, 607-625.

Nataro, J. P., \& Kaper, J. B. (1998). Diarrheagenic Escherichia coli. Clinical Microbiology Reviews, 11, 142-201.

Nou, X., Rivera-Betancourt, M., Bosilevac, J. M., Wheeler, T. L., Shackelford, S. D., Gwartney, B. L., et al. (2003). Effect of chemical dehairing on the prevalence of Escherichia coli $\mathrm{O} 157: \mathrm{H} 7$ and the levels of aerobic bacteria and Enterobacteriaceae on carcasses in a commercial beef processing plant. Journal of Food Protection, 66, 2005-2009.

Nutsch, A. L., Phebus, R. K., Riemann, M. J., Schafer, D. E., Boyer, J. E., Jr., Wilson, R. C., et al. (1997). Evaluation of a steam pasteurization process in a commercial beef processing facility. Journal of Food Protection, 60, 485-492.

Park, C. H., Gates, K. M., Vandel, N. M., \& Hixon, D. L. (1996). Isolation of Shiga-like toxin producing Escherichia coli (O157 and non-O157) in a community hospital. Diagnostic Microbiology and Infectious Disease, 26, 69-72.

Parma, A. E., Sanz, M. E., Blanco, J. E., Blanco, J., Vinas, M. R., Blanco, M., et al. (2000). Virulence genotypes and serotypes of verotoxigenic Escherichia coli isolated from cattle and foods in Argentina. Importance in public health. European Journal of Epidemiology, 16, 757-762.

Paton, A. W., Ratcliff, R. M., Doyle, R. M., Seymour-Murray, J., Davos, D., Lanser, J. A., et al. (1996). Molecular microbiological investigation of an outbreak of hemolytic-uremic syndrome caused by dry fermented sausage contaminated with Shiga-like toxin-producing Escherichia coli. Journal of Clinical Microbiology, 34, 1622-1627.

Phebus, R. K., Nutsch, A. L., Schafer, D. E., Wilson, R. C., Riemann, M. J., Leising, J. D., et al. (1997). Comparison of steam pasteurization and other methods for reduction of pathogens on surfaces of freshly slaughtered beef. Journal of Food Protection, 60, 476-484.

Pitten, F. A., \& Kramer, A. (2001). Efficacy of cetylpyridinium chloride used as oropharyngeal antiseptic. Arzneimittelforschung, 51, 588-595.

Pohlman, F. W., Stivarius, M. R., McElyea, K. S., Johnson, Z. B., \& Johnson, M. G. (2002a). Reduction of microorganisms in ground beef using multiple intervention technology. Meat Science, 61, $315-322$.

Pohlman, F. W., Stivarius, M. R., McElyea, K. S., \& Waldroup, A. L. (2002b). Reduction of E. coli, Salmonella typhimurium, coliforms, aerobic bacteria, and improvement of ground beef color using trisodium phosphate or cetylpyridinium chloride before grinding. Meat Science, 60, 349-356.

Pradel, N., Livrelli, V., De Champs, C., Palcoux, J. B., Reynaud, A., Scheutz, F., et al. (2000). Prevalence and characterization of Shiga toxin-producing Escherichia coli isolated from cattle, food, and children during a one-year prospective study in France. Journal of Clinical Microbiology, 38, 1023-1031.

Ransom, J. R., Belk, K. E., Sofos, J. N., Stopforth, J. D., Scanga, J. A., \& Smith, G. C. (2003). Comparison of intervention technologies for reducing Escherichia coli $\mathrm{O} 157 \mathrm{H} 7$ on beef cuts and trimmings. Food Protection Trends, 23, 24-34.

Riley, L. W., Remis, R. S., Helgerson, S. D., McGee, H. B., Wells, J. G., Davis, B. R., et al. (1983). Hemorrhagic colitis associated with a rare Escherichia coli serotype. New England Journal of Medicine, 308, 681-685.

Rivera-Betancourt, M., Shackelford, S. D., Arthur, T. M., Westmoreland, K. E., Bellinger, G., Rossman, M., et al. (2004). Prevalence of Escherichia coli O157:H7, Listeria monocytogenes, and Salmonella in two geographically distant commercial beef processing plants in the United States. Journal of Food Protection, 67, 295-302.

Rogerie, F., Marecat, A., Gambade, S., Dupond, F., Beaubois, P., \& Lange, M. (2001). Characterization of Shiga toxin producing $E$. coli and $\mathrm{O} 157$ serotype E. coli isolated in France from healthy domestic cattle. International Journal of Food Microbiology, 63, $217-223$

Rourke, T. J., Guerra, M., Kemp, G. K., Tinsley, B. C., Warf, C. C., Richardson, T. G., et al. (2001). Evaluations of acidified sodium chlorite for use on red meats. Available fromhttp:// ift.confex.com/ift/2001/techprogram/paper_5893.htm . Accessed 9.09.03.

Schnell, T. D., Sofos, J. N., Littlefield, V. G., Morgan, J. B., Gorman, B. M., Clayton, R. P., et al. (1995). Effects of postexsanguination dehairing on the microbial load and visual cleanliness of beef carcasses. Journal of Food Protection, 58, 1297-1302.

Schurman, R. D., Hariharan, H., Heaney, S. B., \& Rahn, K. (2000). Prevalence and characteristics of Shiga toxin-producing Escherichia coli in beef cattle slaughtered on Prince Edward Island. Journal of Food Protection, 63, 1583-1586.

Shinagawa, K., Kanehira, M., Omoe, K., Matsuda, I., Hu, D., Widiasih, D. A., et al. (2000). Frequency of Shiga toxin-producing Escherichia coli in cattle at a breeding farm and at a slaughterhouse in Japan. Veterinary Microbiology, 76, 305-309.

Siragusa, G. R. (1995). The effectiveness of carcass decontamination systems for controlling the presence of pathogens on the surfaces of meat animal carcasses. Journal of Food Safety, 15, 229-238.

Small, A., Reid, C. A., Avery, S. M., Karabasil, N., Crowley, C., \& Buncic, S. (2002). Potential for the spread of Escherichia coli O157, Salmonella, and Campylobacter in the lairage environment at abattoirs. Journal of Food Protection, 65, 931-936.

Tilden, J., Jr., Young, W., McNamara, A. M., Custer, C., Boesel, B., Lambert-Fair, M. A., et al. (1996). A new route of transmission for Escherichia coli: infection from dry fermented salami. American Journal of Public Health, 86(8 Pt 1), 1142-1145.

USDA, Animal and Plant Health Inspection Service (2001). Salmonella in United States Feedlots. Available fromhttp://nahms.aphis.usda.gov/feedlot/Feedlot99/FD99salmonella.pdf.

USDA, Animal and Plant Health Inspection Service (2003). Salmonella and Campylobacter on US Dairy Operations. Available from http:// nahms.aphis.usda.gov/dairy/Dairy02/Dairy02SalCampy.pdf.

USDA, Food Safety and Inspection Service (1999). Food irradiation of meat food products, final rule. Federal Register, 64, 72149-72166.

USDA, Food Safety and Inspection Service (1994). Microbiological Baseline Data Collection Program: Steers and Heifers, October 1992-September 1993 (United States Department of Agriculture). Available fromhttp://www.aphis.usda.gov/vs/ceah/ cahm.

US Food and Drug Administration (2003). 21 CFR Part 173, Acidified sodium chlorite solutions. Federal Register, 68, 138-139.

US Food and Drug Administration (1997). 21 CFR Part 179, Irradiation in the production, processing, and handling of food. Federal Register, 62, 64107-64121.

Van Donkersgoed, J., Graham, T., \& Gannon, V. (1999). The prevalence of verotoxins, Escherichia coli $\mathrm{O} 157: \mathrm{H} 7$, and Salmonella in the feces and rumen of cattle at processing. Canadian Veterinary Journal, 40, 332-338.

Wachsmuth, I. K., Kiehlbauch, J. A., Bopp, C. A., Cameron, D. N., Strockbine, N. A., Wells, J. G., et al. (1991). The use of plasmid profiles and nucleic acid probes in epidemiologic investigations of 
foodborne, diarrheal diseases. International Journal of Food Microbiology, 12, 77-89.

Wells, J. G., Shipman, L. D., Greene, K. D., Sowers, E. G., Green, J. H., Cameron, D. N., et al. (1991). Isolation of Escherichia coli serotype O157:H7 and other Shiga-like-toxinproducing E. coli from dairy cattle. Journal of Clinical Microbiology, 29, 985-989.
Xiong, H., Li, Y., Slavik, M. F., \& Walker, J. T. (1998). Spraying chicken skin with selected chemicals to reduce attached Salmonella typhimurium. Journal of Food Protection, 61, 272-275.

Yang, Z., Li, Y., \& Slavik, M. F. (1998). Use of antimicrobial spray applied with an inside-outside bird washer to reduce bacterial contamination of prechilled chicken carcasses. Journal of Food Protection, 61, 829-832. 